\title{
COPYRIGHT PROTECTION ABROAD FOR UNITED STATES CULTURAL EXPORTS
}

\author{
Richard R. Colino*
}

W ITH the advent of the twentieth century, and its continuing remarkable and varied developments in the communication of intelligence, has come an interesting change in the position of the United States of America in the "cultural exchanges" of the world. While during the nineteenth century the United States was an "importer" of culture, during the twentieth century this nation has become an "exporter." This change has been an inevitable accompaniment of the emergence of the United States as a leader, among the nations of the world. The intellectual products of Americans increasingly have entered into the world channels of performance and publication, not only in English, but in all languages. From the earliest days of this century, motion pictures produced by Americans enjoyed unusual acceptance, particularly with the absence of a language barrier during the first thirty years of "silents." Today, with dubbed sound tracks or translated subtitles for the non-English speaking countries, the spectacular pictures, such as "Gone With the Wind," "Around the World in Eighty Days," "Ten Commandments," and "Ben Hur," are compiling receipts in all countries that are spectacular in themselves. Of similarly great importance is the enthusiastic reception of recordings of American "popular" music in most of the market places of the world, including those of the Soviet Union. The older American movies are now moving into foreign television channels. United States producers and publishers comb all possible world sources of material suitable for stage play, motion picture, book, and musical publication and performances, not only for the United States market, but for adaptation into our own unique creative idioms for exploitation domestically and abroad. This is especially the case in our giant motion picture production industry whose American production investments depend upon the expectation that slightly over fifty-four per cent of its income comes from foreign

* A.B. 1957, Amherst College; LL.B. 1960, Columbia University. Member of the New York Bar. 
markets. ${ }^{1}$ It has become commonplace for American motion picture companies to acquire the rights to literary, dramatic and musical works of foreign origin and, by their unique creative adaptations, to transform these works into forms. of "American culture." The enormous temporal, economic and aesthetic investment required in the production of a motion picture necessitates an inquiry as to whether the rights which the producer must acquire and hold are protectible abroad. ${ }^{2}$ The answer to this query may well determine the quantum of "cultural export" by Americans and must precede any agreements to license or sell abroad.

This question brings to the fore the underlying complexities inherent

\footnotetext{
${ }^{1}$ According to the I 960 and 196 I Film Daily Year Books, the world-wide weekly audience for American films is some 200,000,000, of which some 41,800,000 attend the 12,397 conventional and 4,700 drive-in theatres in the United States, and about $158,200,000$ attend the almost 140,000 theatres in other countries. The world-wide film income on American films from rentals to film theatres is some $\$ 600,000,000$, of which $54.5 \%$ is derived from outside the United States for the American producers.

${ }^{2} A$ thorny problem arises in dealing with the question of what protection is available within the United States of America. This nation's system of copyright protection, allocating protection between the state and the federal governments, is possibly to some extent more dichotomous than that of other nations. Other countries will ordinarily protect the works of their authors, under a single national system, from creation to the end of their protectible life, regardless of publication. A work will be protected in the United States from creation, provided the work is never registered or dedicatorily published. This so-called common law copyright protection is obtainable only under applicable state law, whatever it may be. However, from and after first publication or registration in the copyright office, the work is protectible only under a formal federal statutory system of copyright for a limited period of twenty-eight years plus a like renewal term. At common law a work created by the artistic labor of a person, reduced to a concrete form which is permanently identifiable, transferable and examinable per se, is property, although incorporeal, and thereby afforded the same protection available to other forms of personalty against appropriation. This product is afforded perpetual duration in the owner until lost by general publication. In Wheaton v. Peters, 33 U.S. (8 Peters) 591 (1834), the Supreme Court repudiated the doctrine of perpetual rights at common law after first publication of a manuscript and held that the sole protection available after publication was statutory under federal law and for the duration prescribed by statute.

Art. I, $\S 8, \mathrm{cl} .8$ of the United States Constitution is the source of congressional authority for legislation protecting copyrightable works for a limited time. Congress has elected to exercise this power only as to works published with copyright notice, or certain unpublished works deposited and registered for copyright in the copyright office of the Library of Congress, still leaving to the states the protection prior to publication or deposit. Presently protection is available under I7 U.S.C., $\$ \$ 1-216$ (1958), essentially the same statute, with ininor amendments, as enacted some fifty years ago as Act of March 4, 1909, ch. 320, 35 Stat. 1075. (A 1947 revision was mercly a. rearrangement and renumbering of the sections of the 1909 act and contained no substantive changes.)
} 
in a world composed of diverse legal systems. The overwhelming majority of nations have recognized the importance of providing protection to the rights of foreign authors through their own territorially limited laws. The need to reconcile the many differences and provide some means of international cooperation has been recognized by the United Nations, ${ }^{3}$ as well as many of the individual nations. This paper will review and examine the greatly advanced and simplified protection which became available only during the past few years, with the coming into effect of the Universal Copyright Convention in 1955. It will also indicate certain still pending problems requiring solution in the securing of protection abroad of the rights of United States "cultural exporters."

\section{I}

\section{The Pre-Universal Copyright Convention Situation}

\section{The Early Status of the "Exporter" and Bilateral Arrangements}

It is not surprising, perhaps, that our nineteenth century nation, then primarily an "importer" of culture, was similarly insular in the scope of its domestic law and participation in international copyright." Unfortunately, despite the efforts of many, the United States maintained

${ }^{8}$ The United Nations Educational, Scientific and Cultural Organization (hereinafter referred to as UNESCO), has been charged with the duty of promoting collaboration among the nations through education, science and culture. GOODricH \& HAMBro, Charter of the United Nations, Commentary and Documents 334 (1946). See also Doc. No. $3 \mathrm{c} / \mathrm{I}_{10}, 2$ U.N. Conf. Docs. 29, resolution 6.7 (1948); Doc. No. $2 \mathrm{c} / \mathrm{r} 32$, 1 U.N. Conf. Docs. 17 , resolution 2.4.x (1947).

- The Copyright Act of 1790 only afforded the privilege of copyright to citizens and residents of the United States (I Stat. I24); as did the 1831 (4 Stat. 436) and 1870 revisions ( 16 Stat. $212-17$ ).

See 2 Ladas, The INTERnational Protection of Literary and artistic ProperTY 1175 (1938); 2 Henn, The Quest for International Copyright Protection, 39 ConNell L.Q. 43 (1953); Schulman, International Copyright in the United States: A Critical Analysis, 19 LAW \& CONTEMP. Prob. 141 (1954); Solberg, Copyright Law Reform, 35 YALE L.J. 48 (1925); The International Copyright Union, 36 YALE L.J. 68 (1926); The New Copyright Bill, I5 Notre DAME LAw. 123 (1940). See also Chafee, Reflections on the Law of Copyright, 45 CoLuM. L. REv. 503 (1945), for a discussion of general practice under the copyright statute and problems thereunder. More recently, in 1955, a study has been initiated by the copyright office, and a panel of consultants designated by the Librarian of Congress, under the direction of the Register of Copyright, which has the aim of general revision of the federal statutory copyright system. The copyright office of the Library of Congress has publicly issued the individual studies on the sundry phases of the revision problem. The Subcommittee on Patent, Trademark and Copyright of the Senate Judiciary Committee is now printing and publishing such studies. 
all too long a provincial and discriminatory attitude towards the protection of foreign works within the United States. ${ }^{5}$ This attitude resulted in a failure to secure adequate protection abroad for the American "exporter."

The Chace Act ${ }^{6}$ in I89I, although of limited international scope, extended Federal statutory copyright protection to non-resident aliens, ${ }^{8}$ provided certain reciprocal conditions were met by the alien's country. ${ }^{9}$ The existence of reciprocal conditions with another country was to be determined by the President of the United States from time to time. ${ }^{10}$

The protection afforded by the Chace Act to non-resident aliens was an improvement, although by no means completely satisfactory, ${ }^{11}$ insofar as the act required that books, photographs and lithographs must have been printed from type set in the United States, or plates or negatives

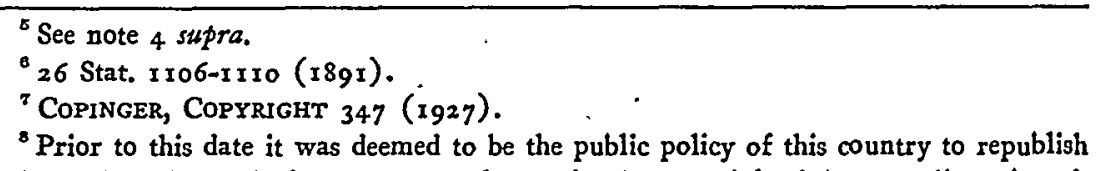
freely within the United States a work previously copyrighted by an alien abroad. Scribner v. Stoddart, 21 Fed. Cas. 876 (No. 12,561) (C.C.E.D. Pa. 1879). A foreigner, resident in the United States, was assimilated to our own nationals, and could secure copyright here on the same basis as a citizen. I7 U.S.C. § 9 (1958).

' These were that the alien's country must grant to citizens of the United States the benefit of copyright on substantially the same basis as its own citizens or that such foreign state be a party to an international agreement providing for reciprocity in the granting of copyright to which the United States may become a party at its pleasure. Act of March 3, 189x, ch. 565, § 13, 26 Stat. 1110.

${ }^{10}$ For a list of countries proclaimed as affording such treatment, see Treaty Affairs, Office of the Legal Adviser, Dep't of State, International Copyright Relations of the United States, reprinted in annotation to 17 U.S.C. \$ 9 (Supp. II 1959-60). An assignment froin an meligible alien author to an otherwise eligible assignee will not cure the lack of standing under title 77 . Bong v. Alfred S. Campbell Art Co., 214 U.S. 236 (1908). In Houghton Mifflin Co. v. Stackpole Sons, Inc., 104 F.2d 306 (2d Cir. 1939), cert. denied, 308 U.S. 597 (1939), a "stateless" author, Adolf Hitler, being ineligible, was able to effect an assignment of "Mein Kampf" to eligible German publishers who secured a valid copyright under title 17. For a discussion of this case, see Smith, The Kampf about "Mein Kampf," 19 B.U.L. REv. 633 (1939). See also Breathitt, Copyright Protection of Aliens and Stateless Persons, 41 KY. L.J. 302 (1953); Note, 49 Y ALE L.J. 132 (1939).

${ }^{11}$ Under the 1891 Chace Act amendment, 26 Stat. 1107 (1891), importation of works requiring such domestic manufacture, or their type, plates or negatives, was prohibited during the existence of copyright therein, except that if the copyright had been so secured only in an English translation of a foreign work in another language, importation was prohibited only as to such translation and not to the uncopyrighted foreign language version from which translated. 
made in the United States. The Copyright Act of $1909^{12}$ somewhat eased the "manufacturing clause" restriction, but this restriction, no matter how mitigated, did tend to inhibit reciprocity, thus keeping the possibility of foreign retaliation against the American "exporter" ever present.

The system of reciprocal national treatment, under primarily bilateral arrangements of the United States with each of some two score nations, as proclaimed by our President from time to time, ${ }^{13}$ in effect called upon the American "exporter" to retain foreign local counsel in each proclaimed country where protection might be desired, first to ascertain, and then, if possible, to comply with the peculiarities of the foreign law. ${ }^{14}$ The expenses and complexity due to the multiplicity and variety of laws, and inadequate methods of local enforcement, made

${ }^{12}$ Act of March 42 1909, ch. $320, \S_{15}, 35$ Stat. 1078 [see 17 U.S.C. $\S_{16}$ (1958)]. It eliminated the requirement of domestic manufacture of works in raised print for the use of the blind, of chromos, photographs or lithographs unless the same were within a book to illustrate its text, and books and periodicals of foreign origin in a language other than English. It also provided for a six month ad interim period of protection within the United States for books or periodicals of foreign origin in the English language while domestic manufacture was being arranged for, if the full term of copyright was desired.

Subsequent legislation eased the stringent statutory requirements. The 1919 amendment, 41 Stat. 369 ( 1919 ), extended the ad interim provisions by allowing deposit with the Library of Congress within sixty days after first publication abroad and extended the temporary protection to four months from the day of deposit. By the Act of August 31, 1954, ch. 1161, § 2, 68 Stat. 1031, 17 U.S.C.A. \$22 (Supp. 1959), permits deposit within six months of first publication and protection extends for five years from the date of first publication abroad. However, the June 3, 1949 amendment, 63 Stat. 154 (1949), provides that protection will lapse after that date unless printing is made in this country.

In conjunction with the 1949 amendments of the ad interim provisions, 17 U.S.C. $\$ \$ 15,22$ wore amended to allow a publisher of English language works by foreign authors to import up to 1,500 copies into the United States during a five year period. 63 Stat. 154 (1949). In the U.C.C. enabling legislation, Act of Aug. 31, 1954, amending 17 U.S.C. $\S 16$, the five year ad interim provision available to foreigners for importation of works in the English language, was similarly made available to our own citizens. That the 1909 domestic manufacturing provisions did not encourage reprinting within the United States, of English language works registered for ad inferim protection, see the copyright office study noted in Chafee, supra note 4, at 524 .

${ }^{13}$ See note ro supra. A recent exercise of this power was Proclamation 3353 Copy-. right Extension: Austria, under 17 U.S.C. $\$ 9$, codified and enaeted into positive law by Act of July 30, 1947, ch. 391, §9, 61 Stat. 655. See Bull. CR: Soc. 112 (Ig60).

${ }^{11}$ In addition to the forty-one nations with which there are proclaimed bilateral copyright relations, there are several nations with which substantially similar reciprocity arrangements for national treatment exist by treaty. See Treaties with Hungary (1912), Siam (1937), and China (1946), in UNESCO Copyright LAWS and TREATIES OF THE WORLD (1959). 
it exceedingly doubtful whether American publishers, producers and authors were actually seeking and obtaining appropriate foreign protection under the informal bilateral relationships.

\section{Multilateral Arrangements}

The United States has been a party to only two multilateral conventions, both exclusively inter-American: The Mexico City Convention of $1902^{16}$ and the Buenos Aires Convention of $1910 .^{18}$ The former seemingly was too cumbersome ever to be utilized ${ }^{17}$ and possibly is in force only between El Salvador and the Dominican Republic, and El Salvador and the United States. ${ }^{18}$ Under the Buenos Aires Convention, membership was limited to the American republics. Reciprocal national protection is contingent upon the meeting of certain requirements. ${ }^{19}$ These requirements are: ( $\mathrm{r}$ ) the work must be the product of a national or domiciliary of a member American republic; (2) the work must be first published in an American republic; and (3) there must be an express reservation of claim to copyright on the, published work. The Buenos Aires Convention has been generally considered applicable only to published works, although there is some question in this regard. ${ }^{20}$ It is also unclear whether compliance with the formalities of the country of origin, and the fixation of the reservation of copyright on the published work, will also satisfy formality requirements under the law of the country whose national treatment is sought for protection under

\footnotetext{
${ }^{15}$ I Ladas, The International Protection of Literary and ARTistic PropERTX 639 (1948) [hereinafter cited as LADAs]. For the conventions, sce CopYrIGHT LAWS AND TREATIES OF THE WORLD, supra note 14, under the heading "Multilateral Conventions."

${ }^{16}$ Text in 2 Ladas i186; also in Copyright LaWs and Treaties of the Wordd, supra note 14, under the heading "Multilateral Conventions." For a recent enumeration of the fifteen Latin-American republics adhering, in addition to the United. States, see annotation in 87 U.S.C.A. $\$ 9$ (Cum. Supp. 1960).

${ }^{17}$ There was the difficult and inpractical requirement of fully complying with the deposit and registration laws of the country of origin, as well as depositing additional copies of the work there to be forwarded by the country of origin, with an accompanying certificate, to other convention countries designated by the applicant. This procedure inust precede a claim of national treatment and protection in the convention country.

${ }^{10}$ Sargoy, UCC Protection in the United States: The Coming Into Effect of the Universal Copyright Convention, 33 N.Y.U.L. REV. 8 II, 852 n.97 (1958); of. HENN, supra note 4 , at $49 \mathrm{n} .33$.

102 LADAS I I 86-88.

${ }^{20}$ See Henn, Interrelation Between the Universal Copyright Convention and the Pan-American Copyright Convention, Universal Copyright Convention Analrzed 225,333 (2955).
} 
article six of the convention. ${ }^{21}$ The difficulties inherent in reciprocal national treatment procedure also are present under this convention and thus the precise utility of the convention is difficult to ascertain. ${ }^{22}$ It seems to afford little assurance to the prospective "exporter" to Latin America.

In 1946, the United States delegation signed the Washington Inter-American Convention on the Rights of the Author in Literary, Scientific and Artistic Works, but the United States has never ratified. It is extremely doubtful whether the United States will every ratify, due, in part at least, to the "moral right" concept, ${ }^{23}$ which would give foreign authors broader protection than is available to Americans. ${ }^{24}$

\section{"Back Door" Protection for Americans Under the Berne Union}

In practice, however, the picture was never so dark for exporting publishers and producers as the limited legal arrangements above described would seem to imply. In fact, without the United States ever

${ }^{21}$ Ladas would auswer the query in the affirmative, viewing the phrase in article three, "without having to comply with any other formalities" as referring to formalities under the law of the forum where protection is sought. I LADAS 661. Article three is set out in 2 LADAS 1186 , where the full convention text is printed.

22 The two reported United States cases involving the Buenos Aires Convention, in the last forty years, have dealt with mechanical reproduction rights to copyrighted music under the convention and held that protection against infringement of music by phonograph records requires an additional separate presidential proclamation of the existence of reciprocal mechanical protection. Todamerica Musica, Ltd. v. Radio Corp. of America, 171 F.2d 369 (2d Cir. 1948); Portuonodo v. Columbia Phonograph Co., 81 F. Supp. 355 (S.D.N.Y. 1937). Hardly anything is known from the other Latin-American member countries of the Buenos Aires Convention how, if at all, any United States works have been protected there.

${ }^{23}$ "Derecho Moral"; Inter-American Convention of 1946, art. XI. See text in COPYRIGHT LAWS AND TREATIES OF THE WORLD, supra note 14 , under "Multilateral Conventions." The doctrine of "droit moral," "derecho moral," or "moral right" is native to continental European jurisprudence. It separates the purely personal rights of the artist from the pecuniary interests he may have in his creation. The concept recognizes that an artist imparts a portion of his very being into the creation which the world beholds. It has been defined as follows:

"The droit moral is the right of an author to crente, to present or refrain from presenting his creation to the public in a form of his choice, to dispose of this form absolutely and to require of everyone respect for its personality in so far as it is intimately bound to his authorial qualities." Michá́lidès-Nouards, LE Droit MORAL DE L'AUTEUR 68 (1935).

For discussions of the doctrine in relation to American jurisprudence see Katz, The Doctrine of Moral Right and American Copyright Law: A Proposal, ASCAP, FoURTH COPYRIGHT LAW SYMPOSIUM 79 (1952); Roeder, The Doctrine of Moral Right: $A$ Study In the Law of Artists, Authors and Creators, 53 HARV. L. REV. 554 (1940).

"See Note, 35 CoRNel.L L.Q. 452, 456 (1950). 
formally adhering to the Berne Union, the United States has been enjoying "back door" protection for works of its citizens in the member countries of the Union, which includes virtually all major countries except the Soviet Union.

In 1878 at Brussels, L'Association Literaire et Artistique Internationale was created by the first Congress of Authors and Artists ${ }^{25}$ as an answer to the piratical publishers of the European lowland countries. After successive annual meetings, the Association approached the formation of a "union of literary property." Finally, in 1883, the Association held a conference at Berne, Switzerland, with the purpose of formulating a definite code of international copyright. The result was the creation of the Berne Union ${ }^{26}$ and the Berne Convention of $1886 .{ }^{27}$

The Berne Union produced a major substantive code of international copyright. ${ }^{28}$ One outstanding feature of the Union is the concept that a work first published in a Berne Union country, regardless of the nationality of the author or whether his country is a member, will be protected for its author or his assignee against infringement in each member country to the same extent that such member nation protects its nationals. ${ }^{29}$ First publication in a Berne country thus creates a Berne Union nationality for the work. This provision affords protection to individual authors whose nations are recalcitrant in adhering to an international copyright convention. By such provision, the Berne Union indirectly opened its protection to American authors, although the United States is not an adherent. ${ }^{30}$ A United States "exporter" of

${ }^{25}$ I LADAS 71 . Victor Hugo was a guiding and powerful force in the creation of the Association.

${ }^{26}$ The original signatory nations were Belgium, France, Germany, Great Britain, Haiti, Italy, Liberia, Spain, Switzerland and Tunis.

${ }^{27}$ Texts of the Berne Union, with its various protocols and revisions, may be found in Copyright LaWs aNd TREaties of THE WorLd, supra note ${ }^{4}$, under "Multilateral Conventions."

${ }^{28}$ It is also often referred to as the International Copyright Union.

${ }^{29}$ Arts. V and VI(I). The union has had several revisions in a constant attempt to meet and cope with the sundry problems that arise. They are the Berlin Revision in 1908 , the Rome Revision in 1928, and the Brussels Revision in 1948. Sce 2 LADAs 1138.

${ }^{80}$ The parties to the convention, as of January 15, 1953, are: Australia, Austria, Belgium, Brazil, Bulgaria, Canada, Czechoslovakia, Denmark, Finland, France, German Federal Republic, Great Britain and Northern Ireland, Greece, Hungary, Iceland, India, Irish Free State, Israel, Italy, Japan, Lebanon, Liechtenstein, Luxembourg, Morocco, Monaco, Netherlands, New Zealand, Norway, Pakistan, Philippines, Poland, Portugal, Rumania, Spain, Sweden, Switzerland, Syria, Thailand, Tunisia, Turkey, 
culture is thus assured that his work will automatically be protected against piracy and infringement in a substantial number of countries, provided that he first publishes his work in a Berne Union country.

One might inquire whether this requirement of first publication in a Berne Union country would not make it impractical for Americans to obtain Berne protection. The Union members answered this question themselves in the Berlin Revision of 1908. Article six of the Berlin Revision provided that automatic protection would be afforded under the convention to works published simultaneously in another country with such first publication in a Berne country. American authors could qualify for full Berne Union protection ${ }^{31}$ by issuing identical release dates for publication in the United States and a Berne Union country, usually Canada or Great Britain. This "back door" protection, by creating a Berne Union nationality for their works, gave Americans substantial assurance of protection of their cultural "exports" in many major countries of the world. It is hardly surprising that Union nations were less than pleased at the prospect of the United States reaping the benefits of Berne protection while offering copyright protection to foreigners only at the risk of difficult United States formalities often observed in the breach. Dissatisfaction culminated in a provision which authorized Berne members to limit Berne protection when a nonUnion country did not protect the work of a Berne Union member adequately.: This did not induce the United States to become a member of the Union nor to revise its diffucult provisions relating to the protection of foreign works. ${ }^{33}$ Although there has been some dispute

Union of South Africa, Vatican City, Yugoslavia. It must be noted that not all of these countries are parties to each revision or even the last revision of the Berne Union.

${ }^{31}$ Under the 1948 Brussels Revision, publication is considered simultaneous in two or more countries, if published within thirty days of first publication. Art. IV(3).

${ }^{33}$ See Additional Protocol to the International Copyright Convention of Berlin, art. 1 , in 2 LADAS $\times 141$. This protocol was incorporated into Art. VI(2)-(4) of the Rome Revision of 1928 .

${ }^{33}$ Various bills were introduced in Congress during the 1930's pointing towards U. S. entry into the Union. Hearings before the Senate Committee on Patents on H.R. 12549, 71st Cong., 3d Sess. (1931); Hearings before House Committee on Patents on H.R. 10976, 72d Cong., 1st Sess. (1932); Hearings before the Senate Committee on Foreign Relations on S. 1928, 73d Cong., 2nd Sess. (1934); Hearings before House Committee on Patents on Revisions of the Copyright Laws, 74th Cong., 2nd Sess. (1936); Hearings before the Subcommittee of the Senate Committee on Foreign Relations on Executive E, 73rd Cong., 2d Sess. (1934), 75th Cong., Ist Sess. (1937). See Note, 5 I HARV. L. REv. 906 (1938). They were opposed by printing interests. Hearings before the Serate Committee on Foreign Relations on $S .1928$, supra, 10-18, 
in Berne countries over the "genuineness" of the alleged simultaneous publication ${ }_{2}{ }^{34}$ there has, however, never really been any retaliation. Nevertheless, the United States was becoming concerned over such a possibility when the project for a Universal Copyright Convention began to be considered after World War II.

In addition to the above noted provisions, the Berne Convention of I886, and subsequent revisions, contain other provisions requiring examination. Protection is available under Berne not ouly from creation to the grave but for a continued term recommended as fifty years after the author's death, ${ }^{35}$ and is now also extended to prevent infringement by adaptations in other media. ${ }^{36}$

Unlike works first or simultaneously published in a Berne country, there is no protection afforded to the unpublished works of nationals of countries not members of the Union. ${ }^{37}$ Thus an unpublished manu-

2I, 27, 89-9I. Radio and motion picture interests opposed the recognition of "droit moral" in article VI of the Rome Revision of 1928 .

34 The Netherlands disputed the claimed simultaneous first publication in a Berne Country by a national of a non-member country in connection with certain Sax Rohmer stories and "Gone With The Wind." In the Sax Rohmer case (De Handelsvenn o.d. firma Uitgevers Mij. "De Combinatie" of Rotterdain v. A. H. Sarsfield Ward) the Supreme Court of the Netherlands (Hooge Raad) held on June 26, 1936, that publication in the United States and simultaneous distribution in Canada did not constitute a simultaneous publication. In the "Gone With The Wind" case (Marsh v. Zuid Hollandsche Boeken Handel Drunkkery) the Sax Rohmer decision was reversed by the Supreme Court, on May 23, I941, and the case remanded to the lower Court. Although World War II interrupted proceedings, the Netherlands later recognized that distribution of a few dozen copies was adequate publication. Dubin, The Universal Copyright Convention, 42 CALIF. L. REv. 89, 99 n.98 (1954); Saher, American-Netherlands Copyright Problems, I WORLD TRADE L.J. 371 (1946).

${ }^{83}$ Brussels Revision of Berne Convention, art. VII(i) (1948). The Berne Union members have recently considered an extension of this term of copyright protection. A meeting of a Committee of Experts in Geneva, January 9-1 1, 1961, produced a Draft Project of an Arrangement Concerming the Duration of Protection of Literary and Artistic Works which would substitute a term of eighty years after the death of the author for the present term. This draft will be subunitted to the diplomatic conference of the Berne members to be held in the Fall of 1961, and, according to one observer:

". . . such an agreement, limited at the beginning to three or four states, may come into existence at the occasion of the next diplomatic conference, even though the overwhelming majority of states regard a term of life plus fifty years as the maximum term for the forseeable future.

"In any event, the recent Geneva Conference indicated a trend toward obtaining an extension of the fifty years term of the Berue Convention in the international law of copyright." Martin-Achard, Meeting of the Committee on Experts Concerning Extension of Copyright Protection (Geneva, Jan. 9-1s, s96s), 8 Bull. CR. Soc. 255, 257 (Ig6I).

"Id., arts. XI-XIV.
"Id., art. IV (1). 
script of an American author may be pirated abroad without protection, in the absence of United States treaty relations with the particular country for reciprocal national treatment, or the failure of the American to have observed the technicalities of the particular foreign country even if there are such treaty relations. When it is considered that a public performance is not a dedicatory publication, and that our unpublished, uncopyrighted plays and music may have been publicized to audiences of millions via radio, television, Broadway and roadshow stage productions, without being deemed dedicatorily published in the United States, one can readily see the importance of this unpublished works exception, but one would, nevertheless, not be justified in complaining that Berne has not also given us "back door" protection for our unpublished works.

On the whole, the Berne Union is an outstanding source of international substantive copyright protection. Unfortunately the United States and other American republics, though garnering "back door" benefits from the Berne Union, have not extended protection to foreigners comparable to that received. It must be appreciated, of course, that the basic concept of the Berne System-a code of international substantive copyright recognizing automatic copyright protection from creation without formality ${ }^{38}$-differed greatly from the United States concept in such regard. The necessity for at least some common recognition of minimal standards of protection, and for the easier exchange of national treatment on a non-discriminatory basis vis-à-vis nationals and aliens, for unpublished as well as published works, proclaimed the need for further international cooperation and development in this field. Particularly, there was a need to bring the United States and the other countries of the world into one copyright agreement.

The Coming into Effect of the Uniform Copyright Convention

A spirit of cooperation and respect for the dignity of man's creations is seen in a statement from the Universal Declaration of Human Rights: "Everyone has the right to the protection of the moral and

${ }^{3 a}$ This was deemed by one writer to be the singularly outstanding provision of the convention. Foster, International Copyright Protection, 3 S.C.L.Q. 60, 69 (1950).

${ }^{\text {so }}$ The full text of the Universal Declaration of Human Rights may be found in 43 AM. J. INT'L L. 127 (Supp. 1949). 
material interests resulting from any scientific, literary, or artistic production of which he is the author."10

As has previously been noted, ${ }^{41}$ the United Nations designated UNESCO as the agency charged with the responsibility of investigating, studying and recommending solutions to the problems of improving international copyright. With the aid of a committee of experts and the cooperation of most of the important countries throughout the world, ${ }^{12}$ UNESCO effected, in June 195I, a preliminary study "Draft of the Universal Copyright Convention." ${ }^{34}$ Finally, at Geneva, in September of 1952, this draft was re-worked and the Universal Copyright Convention enacted, which some forty nations then formally approved.44 The Universal Copyright Convention came into effect on September I6, $1955^{45}$

The U.C.C. was intended to provide common minimal standards of protection without impairing any conventions, treaties or systems presently in force. ${ }^{46}$ In terms of protection abroad for our cultural "exports," "47 the U.C.C. is important primarily because: ( $I$ ) it gives a simple protection abroad to published and unpublished works of United States origin and (2) it assures United States "importers" of being able to obtain exclusive rights in works of foreign origin intended for United

${ }^{10} 1 d$., art. 27. This statement was specially approved by the United Nations General Assembly on December 10, 1948. U.N. Doc. A/811, Dec. 16, 1948; 43 AM. J. INT'L L. ${ }_{32}$ (Supp. 1949).

${ }^{41}$ Note 3, supra.

${ }^{42} \mathrm{Kuhn}$, The Work of Unesco on Copyright, 43 AM. J. INT'I L. 343 (1949).

${ }^{43}$ IV UNESCO COPYRIGHT Bull. 7 (No. 3, 195 I).

"See V UNESCO Copyright BuLl. 187 (Nos. 3-4, 1952). The text of the Universal Copyright Convention may be found in Copyright LAWS AND TREATIES of THE WORLD, supra note 14, under "Multilateral Convention"; [1955] 6 U.S.T. \& O.T.A. 273 I, T.I.A.S. No. 3324.

${ }^{45}$ The United States Senate ratified on June 25, 1954. 100 CoNG. REC. 8945-53 with accompanying enabling legislation.

10 Arts. XVII, XVIII, XIX; VI UNESCO CopYright Bull. 40-44 (No. I, I953). See generally Dubin, note 34 supra.

${ }^{47}$ For an extensive and penetrating treatment of the other side of the problem here considered, namely, U.C.C. protection in the United States for alien claimants, from which the writer drew heavily, see Sargoy, supra note 17. See also Finkelstein, The Universal Copyright Convention, 2 AM. J. CoMP. L. 198 (1953); Henn, supra note $4 ;$ Schulman, supra note 4; Sherman, The Universal Copyright Convention: Its Effect on United States Law, 55 CoLuM. L. Rev. 1137 (1955); Warner, The UNESCO Universal Copyright Coswention, r952 W1s. L. REv. 493 (opposing United States ratification); Dubin, supra note 34; Note, International Copyright Protection and the United States: The Impact of the UNESCO Universal Copyright Convention on Existing Law, 62 YALE L.J. 1065 (1953). 
States adaptation and world-wide marketing, while at the same time making compliance with federal law facile.

Of what importance is it to the United States "exporter" that foreign works are now easier to protect, not only within the United States, but in other countries to which he will export the adaptation? The answer is that it is vital for the United States "exporter" to be assured of exclusive rights when he makes substantial investments and to be able to recoup them on both a domestic and world-wide basis. He cannot afford to expose himself to the risk of another producer or publisher having equal access to his foreign sources. The question now to be addressed is what do the U.C.C. provisions do toward furthering these objectives?

The U.C.C. is initially modest in that, unlike the Berne Union, substantive provisions are left to the domestic laws of member countries. $^{48}$ While there are minimal substantive requirements, ${ }^{49}$ the main emphasis is upon providing a ready means of exchanging national treatment. The United States "exporter" is given a single simple method of obtaining recognition and protection of his works in each of the member countries to the same extent that the member country protects its own nationals.

\section{Unpublished Works}

As to unpublished works, the U.C.C. provides $^{50}$ that every member country shall protect the unpublished works of nationals of other member countries to the same extent that it protects the unpublished works

${ }^{18}$ This is not too surprising when one considers the diverse legal systems and concepts to be found among the member nations. The granting of copyright as a private right for a limited period under the United States statute rests on the premise, stated in the U.S. Constitution art. $I, \S 8$, that a copyright is a privilege to be conferred in. the public interest to encourage the arts and ultimately enrich the public, whereas the Berne Union is predicated on the assumption that the private right of property of the author is the matter of the paternal right of the author to the product of his artistic or intellectual labor. The U.C.C., necessarily, was also the product of a reconciliation of certain Berne Union and United States concepts of copyright. Preliminary Observations, V UNESCO COPYRIGHT BulL. 72 (No. 1, 1952).

${ }^{\circ(1)}$ There is a minimum period for duration of protection under art. IV(2); (2) there is a guaranty of exclusive translation rights for at least seven years, followed by a type of compulsory license provision in art. V; (3) the U.C.C. notice of copyright, the symbol (C), will be used, from and after first publication, in place of all other formalities precedent to copyright in the country where protection is sought (art. III (1)); (4) under art. III(4) each contracting state must provide "legal means" of protecting, without formalities, unpublished works of nationals of other member nations.

${ }^{\circ 0} \mathrm{Art}, \mathrm{II}(2)$ 
of its own nationals. This affords the American more certainty of protection abroad, in U.C.C. nations, than he may heretofore have had. ${ }^{\text {s1 }}$

\section{Published Works}

In dealing with published works, the U.C.C. embodies two concepts. $^{52}$ First, it adopted the United States concept of publication of a work with notice of copyright. Under the federal copyright statute, except as to a few kinds of unpublished works for which copyright may be secured by deposit of a manuscript in the copyright office, publication of a work with notice of copyright is the general requisite to the securement of copyright. ${ }^{53}$ The U.C.C. retains this "notice" concept, providing that protection in all member countries shall be afforded upon first publication ${ }^{54}$ with the U.C.C. notice. Such notice consists of:

\footnotetext{
${ }^{81}$ Sargoy, supra note 17 , argues that Congress, although not mentioning unpublished works in its enabling amendment of 17 U.S.C. by Public Law 743, nevertheless implemented, by implication, the U.C.C. requirement that protection must be given during their unpublished stage to works of nationals of other member countries. He contends that such implementation was effective only as to those types of unpublished works which are protectible under 17 U.S.C. when published or deposited, i.e., writings in visually identifiable form, so that the convention became the law of the land, calling upon state courts to protect such visually identifiable works in their unpublished stage when protection was sought therefor by a foreign U.C.C. claimant or his United States assignee.

${ }_{82}$ Arts. II(I), III(I).

${ }_{17}$ U.S.C. \$ 10 (1958).

st U.C.C. art. VI defines publication as "the reproduction in tangible form and the general distribution to the public of copies of a work from which it can be read or otherwise visually perceived." This quite obviously eliminates public sale of recordings of music, drama, etc. as "publication" within the meaning of the Convention, either as to the intellectual content so recorded, or as to the artistic performing interpretation or rendition captured on the record.

The law in the United States is not fully settled as to whether the public sale of phonograph recordings is a "publication." In Waring v. WDAS Broadcasting Station, Inc., 327 Pa. 433, I94 Atl. 631 (1937), the Supreme Court of Pennsylvania sustained the common law right of an orchestra leader, Fred Waring, to enjoin radio broadcasts of his recorded artistic rendition of a song despite the fact that the records were sold to the general public. In RCA Mfg. Co. v. Whiteman, I14 F.2d 86 (2d Cir.), cert. denied, 3 II U.S. 712 (1940), the court denied relief on the ground that the common law right in the fixation of the artistic rendition to the sound track was dedicatively published by the public sale of the records, using language broad enough to include rights in the song. The Second Circuit has more recently held that public sale of authorized recordings did not constitute a dedicatory publication of common law property rights in the fixation of the performance therein, overruling the principle of the Whiteman case. Capital Records, Inc. v. Mercury Records Corp., 221 F.2d 657 (2d Cir. 1955). This was an unfair competition case, applying common law rather than federal statutory principles, and the majority of the Court of Appeals felt it had
} 
(I) The symbol $C$, since other nations do not have an equivalent word for our word of art, "copyright";

(2) The name of the copyright proprietor;

(3) The year date of first publication. ${ }^{58}$

This notice may be inserted anywhere in the work where it will give "reasonable notice." If a work is first published in this manner, complete and non-discriminatory recognition and protection, to the extent of the substantive domestic law, will be conferred throughout member countries, without the necessity of complying with requirements of particular domestic law that bear upon basic recognition and continued enjoyment of a copyright. 58

In addition to the above concept, the U.C.C. also embodies one of the major concepts of the Berne Union. A work first published in a U.C.C. country with the appropriate U.C.C. copyright notice acquires a U.C.C. nationality of its own and will be protected in all member countries regardless of the author's nationality. ${ }^{59}$ There is an exception,

to rely in a diversity case on New York law, as laid down in Metropolitan Opera Ass'n v. Wagner-Nichols R. Corp., 199 Misc. 786, ror N.Y.S.2d ${ }_{48}$ (Sup. Ct. 1950), aff'd, 279 App. Div. 632, x07 N.Y.S.2d 795 (195x), for its conclusion. Several states have enacted statutes providing for the loss of common law property rights in recorded artistic renditions of copyrighted music by public sale of the performers' recordings. Fla. Stat. ANN. § 543.02-.03 (1943); N.C. Gen. STAT. ANn. § 66-28 (1960); S.C. CODE ANN. $§ 66-101$ (1952). Some dicta exists as to the public sale of music recordings being dedicatory of the uncopyrighted song therein. Mills Music, Inc. v. Cromwell Music, Inc., 126 F. Supp. 54, 69 (S.D.N.Y. 1954); Shapiro, Bernstein \& Co. v. Miracle Record Co., 91 F. Supp. 473, 475 (N.D. IIl. 1950).

It would seem that the U.C.C. would not consider a performance or the sale of a record the publication of either the artistic rendition or the song itself. For an analysis of the possible effects of art. VI on domestic law, see Sargoy, suppra note 17 , at $8 \mathrm{I}_{3}-\mathrm{I}_{4}$, 822-25.

${ }^{86}$ Many nations employ phrases which refer to the right of authorship, e.g., "Le Droit D'Auteur" (French); "EI Derecho De Autor" (Spanish); "Il diritto Di Autore" (Italian). The German "Urheberrecht" is translated as copyright.

${ }^{80}$ U.C.C. art. III (1).

${ }^{87}$ U.C.C. art. III(I). This provision is in contra-distinction to the rigid placement requirements under the federal copyright statute. I7 U.S.C. $\$ 20$ (1958) requires that in the case of a book or other printed publication the notice must appear upon the title page or the page immediately following. There are sinnilarly strict requirements for other works.

${ }^{8}$ U.C.C. art. III(x). The United States national may, however, be required to observe procedural formalities in U.C.C. member countries as a condition precedent to suit, such as depositing a copy or copies of his work, retaining local counsel, etc., but these do not affect the basic right to continued recognition of his copyright. U.C.C. art. III(3). For the procedural formality required under title 17 , see note 62 infra. Art. II(I). 
however, to this general provision, which permits any nation so desiring to exclude from U.C.C. protection any works first published within its territory, or works of its own nationals published anywhere. ${ }^{00}$ The United States has exercised its right to exclude these works from U.C.C. protection and leaves them solely dependent upon strict compliance with domestic United States law for protection. ${ }^{61}$ Several examples may better illustrate this point.

Let us suggest that Jones, a United States citizen, first publishes a book in an English language edition, using the (C) form of notice, in France. What protection will be available to him? The answer is that he will be extended protection in the United States, assuming compliance with its statutory placement requirements, under the federal copyright statute, ${ }^{62}$ and not the U.C.C. $\mathrm{He}$ will be protected under the U.C.C. against infringement in all other U.C.C. countries without further formalities.

Assume the same facts as above, except that instead of the symbol (C) Jones uses the word "Copyright." What result? Again, he will be protected within the United States, assuming compliance with statutory requirements, under the federal copyright statute. His work will not be protected abroad under the U.C.C. since he has not affixed the (C) as notice of his copyright claim. He might, however, still be protected under some bilateral arrangements in certain countries.

If Jones, a U.S. citizen, or Green, an alien domiciled here, regardless and places the (C) on a page other than the title page or next subsequent page of a book or periodical, will there be protection? Since first publication within the United States precludes U.C.C. protection in this country, protection is secured here only if there has been strict compliance with federal copyright law. The wrong placement of the otherwise good notice eliminates domestic protection in the United States. However, the author or his assignee may be entitled to protection under the U.C.C. in other U.C.C. countries if his notice was placed so as to give reasonable notice.

If Brown, a non-resident alien, first publishes abroad with the symbol (C) affixed to the last page of his work, what result will obtain?

\footnotetext{
${ }^{\circ}$ U.C.C. art. III(2). .

${ }^{61}{ }_{7}$ U.S.C. \& 9 (1958).

-2 Procedural formalities in the U.S. such as deposit of copies and registration of the claim to copyright under I7 U.S.C. I3 $_{3}$ (1958) are.merely conditions precedent to. suit, and. are. not necessary to continued validity or future protection against in. fringement. Washingtonian Publishing Co. v. Pearson, 306 U.S. 30 (1939).: :"
} 
The work will be protected, under the U.C.C., in the United States and other U.C.C. nations, as meeting U.C.C. requirements. If Brown so publishing abroad were a United States citizen or domiciliary, he would not be eligible for U.C.C. protection in the United States, although he would in other U.C.C. countries, because he failed to meet the United States domestic standards as to placement of the notice.

If Jones, a U.S. citizen, or Green, an alien domiciled here, regardless of the country of which he is a national, first publishes in the United States with a (C) copyright notice on the title or following page of the book containing his name as author and the year date of such first publication, will he be protected? These authors have used a very satisfactory method. They not only are assured of full protection under our domestic statutes, but also automatic recognition and the right of enjoyment and protection of their copyrights in every U.C.C. country. This is an enormous advantage over the earlier bilateral method, under which individual compliance had to be made with the laws of some two score or so countries. Even a better method, for the extra cautious owner, is also to make a simultaneous publication in a Berne country such as Canada or Great Britain, in addition to the United States. This will assure Berne Union protection as well, and particularly will assure protection in those Berne Union countries which have not yet adhered to the U.C.C. To insure protection in Latin America the Buenos Aires Convention form of notice should also be utilized. ${ }^{63}$

Thus, it will be seen that the Berne concept, incorporated into the U.C.C., of protection to works first published in a member country, gives a simple direct protection to Americans. As regards most important Berne countries, already in the U.C.C. orbit, the American "exporter" need no longer concern himself with the imperative question of the adequacy of an intended simultaneous publication in a Berne country, which probably often was not as simultaneous as hoped, if indeed the publication outside the United States was actually effected at all. An American participating in a world-wide enterprise now has his problems considerably ameliorated. ${ }^{64}$

\footnotetext{
"As "All Rights Reserved" ("Dereches Reservados"), Buenos Aires Convention of 1910 , art. 3.

${ }^{\circ}$ This is not to imply that all of his problems have vanished. There are still problems of perfecting technical licensing agreements as well as general economic questions. An "exporter" may face formidable obstacles in the guise of import duties, quotas, exchange controls, frozen income and trade restrictions. As an example it may be noted that until recently the motion picture "exporter" could only, withdraw from
} 


\section{A Typical Problem}

What effect will the U.C.C. have in a typical American business situation-that of the United States enterpreneur who has acquired an original work of foreign origin for creative American adaptation and subsequent exploitation in domestic and world markets? Let us assume the following hypothetical situation. A major motion picture is to be produced by a United States corporation for exhibition in domestic and world markets. The picture is to be based on an outstanding literary work created by a national of the Soviet Union, which is neither a member of the U.C.C. nor the Berne Union, nor has any copyright relationships whatever with any nation. The author makes arrangements with a French publisher for publication in France ${ }^{85}$ in the author's native language, as well as in a French language translation. The work gets world-wide acclaim and the United States motion picture producer intends to produce a super-spectacular film of it. Millions of dollars in assets of the producer are "frozen" in Spain. Arrangements can readily be made to obtain the necessary actors and equipment for filming in that country. Plans have been made to do studio shots and film editing in Hollywood. For advance exploitation, and to create a movie audience from readers, the producer intends to make arrangements for publication of a pre-release bound edition of the original work, translated into English, in the United States and other English speaking countries. This will be followed by a paperback edition of the English translation of the work during the release of the picture. Since the income derived from motion pictures exhibited within the United States is ordinarily less than forty-six per cent of the world-wide gross income, ${ }^{68}$ and often not enough to recover production costs, the producer must be assured of foreign protection of its exclusive rights in the publication of the motion picture and book.

The producing corporation is able to get United States copyright

the United Kingdom a small percentage of the income earned there, and income from motion picture distribution was likewise "frozen" in many other foreign countries, for local expenditure there. Many nations "freeze" the funds of American individuals and corporations by requiring that all or a given percentage of the receipts derived from sales within that nation be spent there. This may be a dominant economic consideration in many business ventures. The "super" motion picture production "Ben Hur" was, for the most part, filmed in Italy because the producers had fifteen million dollars "frozen" there.

's France is a party to the U.C.C., and is also a. Berne Union member, and has reciprocal relations with the United States.

"Suppra note 1. 
for its own authorship, ${ }^{67}$ i.e., the motion picture production, but if the story, characters, plot, incidents, etc., of the original manuscript are in the public domain, or otherwise unprotectible, then there would be a risk of competition. This could come from other motion picture productions, competing literary translations, or even other media, such as radio and television dramatizations, and live stage plays, not only within the United States but abroad. Clearly the issue is how much protection can the producing corporation secure.

\section{A. Prior to the U.C.C.}

If the work had first been published in the Soviet Union, which has no copyright relations with other nations, then the work would have fallen into the public domain of all nations. This would have resulted in making the plot, story, characters, incidents and foreign language word arrangements available to anyone wishing to use them. The only work protectible in the United States would be the French translation if "authored" by an eligible French translator. Protection would extend, however, only to the eligible translator's individual contribution of authorship, i.e., his translative word arrangements, and not the original ineligible author's contribution of story, plot, characterizations, incidents, etc. Under these circumstances, it would be very unlikely that a United States motion picture company would be willing to invest in a production, since the possibility of competing production would be too great.

On the other hand, if the first publication were in France, a Berne Union country, rather than in the original author's own ineligible country, in an edition authorized by him either of his original language version or his own or an authorised French translation, the author would be protected in all Berne Union countries, regardless of the lack of relationship with his own country. But what protection would be available in non-Union countries, such as the United States? Prior to the U.C.C., the basic copyright relations the United States had, excluding the Pan-American conventions, provided bilaterally for reciprocal national treatment for citizens or subjects of proclaimed nations. Since the author in this case is not a citizen or subject of France, French publication, either in the original language or translated, would

\footnotetext{
${ }^{87}$ This is not necessarily so throughout the world, since corporate authorship is not always recognized. See Des BoIs, Le DroIT D'AUTEUR, 184 (1950). See also the French Copyright Act of March 11, 1957, arts. 1, 14, and 18, set out in 15 Reouse Internationale Dut Droit $D^{\prime} A u t e u r, 164-177$ (1957).
} 
throw the work into the United States public domain. The ineligible author cannot cure this defect by assignment of his work prior to publication to an otherwise eligible assignee, i.e., a publisher who is a French or a United States national. The work still would not be protected in the United States. ${ }^{68}$ Again, it is still probably too risky a venture, in the absence of exclusive rights, for the United States motion picture producer.

\section{B. Post U.C.C.}

If the work is first published in the Soviet Union, the result will be the same as if the U.C.C. had not come into being. The work will fall into the public domain with the earlier mentioned results.

What result if the author in this case authorizes a first publication in France, either in his original language or in a French language translation either by himself or another? If the proper U.C.C. notice of copyright is affixed to the work and first publication is made in France, then the United States would be obligated, as would all other U.C.C. members, to extend the full scope of its substantive domestic protection to the otherwise ineligible author or owner of this work. The Berne Union principle, carried over into the U.C.C., as discussed earlier, ${ }^{89}$ would have the effect of extending protection to a work not otherwise protectible. Such protection, either in the original language version or authorized translation, if the latter be first published, would cover the entire work, including plot, story, characterization, incidents, and word arrangement. Assuming the motion picture corporation acquires all rights, ${ }^{70}$ then no part of the work will fall into the public domain. The corporation will be assured of exclusive control of all rights in the United States, and protection against infringements in any

${ }^{68}$ See Bong v. Alfred S. Campbell Art Co., 214 U.S. 236 (1908).

"See text at note 59 supra.

${ }^{30}$ It is important to acquire all possible rights so as to prevent the use of the work in any media in derogation of the motion picture production. If it proves impossible to acquire full rights, since the author may only have been willing to convey to the present publishing proprietor the right to publish a French language edition, some protection may perhaps be obtained by contractual agreement. In contracting to purchase the exclusive motion picture rights from the French publisher the producer will insist on including a covenant whereby the publisher, or author where possible, agrees not to convey or exploit rights in competing media for a period of years, often seven to twelve. This would be highly effective in the instant situation, since the purchase price might likely be based on a percentage of earnings which could be withheld if the covenant were breached. See note 72 infra for indication that under French law an author must continue to share in the future proceeds from the exploitation of his work. 
media throughout U.C.C. nations. It is this type of assurance that induces businessmen to invest.

The U.C.C. affords American "exporters" greater direct protection than they might obtain under domestic law without abridging whatever protection is available under other conventions, reciprocal bilateral arrangements, or the Berne Union. As an example, the American will have the benefit of protection of the author's "droit moral," a concept prevalent in many countries throughout the world, which he does not have in the United States. The Report of the Rapporteur-General ${ }^{71}$ of the U.C.C. indicates that production and performance rights, generally extended abroad, will be fully extended to the American author. ${ }^{72}$

\section{III}

\section{Some Post-Universal Copyright Convention Problems}

The advent of the U.C.C. made a significant advance in international copyright arrangements, particularly in achieving greater harmony in the first step of exchanging national treatment on a more simplified

\footnotetext{
${ }^{71}$ IV UNESCO Copyright BULlETIN 46-47 (No. 3, 1951 ).

${ }^{22}$ For the assertion that certain provisions of domestic law will not be extended by the U.C.C. or Berne Union, see Rothenberg, The New French Copyright Act: Article 35, 5 Bull. Cr. Soc. 12 (1957). The author takes the position that Article 35 of the French Copyright Act of March 11, 1957, abolishing lump sum remuneration by which an author forsakes all future interest in the exploitation of his work, will not apply in France to non-French works. For an interesting discussion of this new innovation in French law, see Tournier, The French Law of March 15, 1957 On Literary and Artistic Property, 6 BuLl. CR. Soc. I (1958).

For an opinion that another concept will be available to U.C.C. claimants in France, see Hauser, The French Droit De Suite: The Problem of Protection for the Underprivileged Artists under the Copyright Law, 6 BuLl. Cr. Soc. 94 (1959). At 110, the author states:

... it would follow that the droit de suste is part of the sum total of author's rights and properly falls within the coverage of the Universal Copyright Convention. At the present time this remains an untested proposition. It is of importance to the American copyright lawyer simply because now, with the enactment of the U.C.C., American artists whose works sell in Belgian, French or Italian markets can, in our opinion, enjoy the benefits of the droit de suite under the assimilative principle of the U.C.C. Reciprocal legislation is, therefore, no longer a requisite for the enjoyment by American artists of the benefits of the droit de suite in those Convention countries having adopted it.

The "droit de suite" is a concept first found in French jurisprudence. It confers upon an artist, the creator of an original work of art, and his heirs, the right to a levy or commission in the form of a percentage of the price in the public sale of his work of art. The right is based partly on the droit moral concept that the creation embodies part of the personality of the creator. It is applicable to artists, sculptors, designers and the like.
} 
basis. : Obviously there are further advances yet to be attained, and some problems still remain to be settled.

\section{The Content of the Copyright Notice}

The U.C.C. relies for its substantive law primarily upon the particular substantive law, whatever it may be, of the country in which a foreign U.C.C. claimant is seeking protection. A major principle of the U.C.C. is the utilization of the (C) notice of copyright containing the name of the "owner" and year date of first publication. But what substantive law is to govern the question of who is the "owner" for the purpose of proper designation in the "notice"? Each country represents a potential market for a work, in one or another of its various forms. Thus, the original owner.may give the British rights in a work to one owner, the French rights to another, the American rights to another, the more embracing Latin-American, or Scandinavian, or western hemisphere rights to still another. What is the appropriate "owner" name which must be utilized in the particular copyright notice in the respective territories for which regional rights have been assigned? An author is, of course, the original owner, if he has not assigned his rights, and his name could appropriately be included in the copyright notice as "owner." However, the copyright systems of the various countries differ as to definitions of authorship. Some countries, of which the United States is typical, recognize corporations which create works through employees for hire as "authors," while countries which follow the French lead recognize as "authors" only individual creators, and protect corporations only as owners by assignment from the individuals.

\section{Electronic Visual Recordings and the Definition of Publication}

A further problem under the U.C.C. is that the definition of "publication" in article six provides for the public sale or distribution of tangible copies of the work only in a form which is visually perceptible. This not only precludes public sale of musical recordings from ever being deemed a publication, but fails to take into consideration recordings of visual and auditory materials on electronic tape or wire, copies of which are not visually perceptible, although capable of visual and auditory perception when electronically activated; also, which may not be distributed in copies but as a single tape or wire sent from one television station or theatre to another for repeated performances throughout the country or world. The above, of course, is a problem which also requires solution in the domestic law of the United States, operating 
under a fifty year old statute which never contemplated such electronic marvels, as it requires solution too in the domestic law of various other countries. $^{78}$

The foregoing remain unanswered problems for future revision of the U.C.C. and may possibly be taken up by the Intergovernmental Copyright Committee for the U.C.C., appointed by UNESCO, at some future meeting, perhaps jointly with representatives of the Berne Union. The Committee has already singled out several problems at past meetings, as noted below, for special consideration and discussion.

\section{The Position of the Copyright Notice}

The second annual meeting of the Intergovernmental Copyright Committee, in Washington, D.C., in 1957, produced an advisory statement $^{74}$ suggesting the proper placing of the notice provided for in article three, paragraph one, of the U.C.C. ${ }^{75}$ At the Committee's first session the representative of Japan had raised the question of proper placing of the symbol (C), since in Japan books and reviews began on what would be the last page in Europe, and whether a newspaper proprietor who had placed the symbol (C) at the top of the first page of his newspaper could claim copyright in all contents of the newspaper that were eligible for protection. The Committee conducted a preliminary discussion of the problem and then requested that a legal study of the national legislation of the contracting states be made and reported on at the Committee's next session. This was done and resulted in the aforementioned advisory statement, which attempts to state broad guidelines in aid of facilitating protection. ${ }^{78}$ The Committee suggested: (I) that placing the notice in books or pamphlets on the title page, or the page immediately following, or at the end of the book or pamphlet would satisfy the requirement of article three, paragraph one, as to location; (2) that in the case of newspapers, magazines or other periodicals, the

${ }^{70}$ This problem may soon be squarely raised in light of an historic instance which occurred on April 19, 1961, when the copyright office accepted a magnetic video tape for registration. Questions are raised:

I. As to the meaning of "writings" in article I, section 8, of the Constitution;

2. As to the protection from infringement of "any transcription or record" under I7

U.S.C. $\S \S$ I (c), I (d), 4, 5 (1958);

3. As to "publication" under the U.C.C.; and

4. As to "publication" under the Berne Union since first publication was in Canada, a

Berne member. See note 54 supra.

${ }^{7} \mathrm{X}$ UNESCO COPYRIGHT BULlETIN 225 (No. 2, 1957).

${ }^{75}$ See note 57 supra.

$76 \mathrm{X}$ UNESCO COPYRIGHT BULLETIN 248 (No. 2, 1957). 
placing of the notice under the main title or the "masthead" would suffice as to the location requirement. Similar views were expressed as to printed music, maps, photographs, motion pictures and other protectible works. The advisory statement does not purport to envisage solutions to problems arising as to works not listed nor those a product of peculiar local practice. These will have to be met as they occur.

\section{Comparison of Terms of Protection by Countries}

Some question also exists as to the application of article four, paragraph four, of the U.C.C.- the "comparison of terms" clause whereby the period of protection fixed by the law of the country where protection is claimed may be replaced by any shorter period fixed by the law of the country of origin of the work. The Intergovernmental Copyright Committee discussed this clause at its first session ${ }^{77}$ and defined the problems which would confront a nation in the application of the clause as follows:

(I) The compulsory or optional character of the comparison of terms;

(2) The consequences of the absence of specific legislative or other measures in regard to a comparison (optional) of terms:

(a) Should it be assumed that contracting states will, or will not, make use of the comparison?

(b) Can contracting states which do not in general make provision for the comparison invoke it nonetheless, if they so desire?

(3) The application of the comparison of terms to certain works not protected in their country of origin (because they do not fall within any class of protected works or because the formalities have not been complied with).

The Committee emphasized the effect that a construction of this clause could have on the general principle of national treatment if states were to use their power to make a comparison of terms. Nevertheless, the Committee in its report ${ }^{78}$ refrained from expressing a view on this matter. A literal reading of article four, paragraph four, coupled with statements made in the Committee or at the Geneva Conference, would indicate the comparison of terms to be an optional system and thus in conformity with the general principle of national treatment.

There are several possible solutions to the query propounded in 2(a)

\footnotetext{
${ }^{77}$ See Summary Records, paragraphs $301-47,602$, in IV UNESCO CoPYRIGHT BULLETIN (No. 2, 1956).

${ }^{78}$ X UNESCO COPYright BUlletin 211 (No. 2, 1957).
} 
above. One would be that in the absence of any explicit provision, the comparison of terms cannot be applied. This would give full adherence to the principle of national treatment. An antithetical solution would be to discard the general principle of national treatment by having the term of protection accorded by a contracting state for a work originating in another contracting state derive directly from the law of the latter state. A third solution would depend on a conflict of laws theory. Once the foreign author has been assimilated to national authors as regards the conditions for the enjoyment of copyright, the applicable law would be determined in accordance with the conflict-of-laws rules in effect in the contracting state.

A solution to the question formulated in 2(b) would involve consideration of international law relating to the continued existence, or renunciation, of a right to invoke a provision contained in an international convention. This problem is beyond the purview of this article.

Finally, the solution to three above, turns on the obligations created under the U.C.C. Contracting states are not obliged, although they may do so, to protect those works of a class not protected in the country of origin. However, failure to comply with all formalities of the country of origin, resulting in lack of protection, will not excuse other contracting states of the obligation to extend protection. The final solution to these problems arising under article four, paragraph four, of the U.C.C. is yet to be awaited.

\section{Pseudonymous and Anonymous Works}

There has been some question as to the protection afforded pseudonymous and anonymous works by the U.C.C. The U.C.C. left the question of the means of protection to the national legislation of the various contracting states. Much of the difficulty stems from the fact that certain legislative provisions, as discussed earlier, consider only natural persons as authors, whereas others recognize that a juridical person can be the author of literary or artistic works. The Intergovernmental Copyright Committee, in considering the question, has taken the position ${ }^{79}$ that the terms of article two, paragraph one, of the U.C.C. protect pseudonymous and anonymous works by a general reference to national legislation. In view of the fact that, as a practical matter, this problem has not arisen as yet, an authoritative solution would be premature.

\footnotetext{
${ }^{70}$ X UNESCO COPYRIGHT BULLETIN 216 (No. 2, 1957).
} 


\section{Adequate Local Remedies}

Another problem still to be resolved centers about preventive action to be taken in case of copyright infringement in foreign countries.' The U.C.C. merely provides for "adequate and effective" protection, and if civil remedies are afforded, the obligations are deemed to have been met. However, the costs involved in pursuing a civil remedy may be so expensive as to render the guarantees of article one illusory if the proceedings are against delinquents in foreign countries. Other forms of assisting injured parties may be more effective. A proposal has recently been submitted to the Intergovernmental Copyright Committee which could bring about this desirable end. The Government of India instigated a proposal which resulted in a resolution by the Committee inviting its Secretariat to prepare, in collaboration with the Bureau of the Berne Union, a summary of statutory provisions for resort to criminal proceedings, or the use of other forms of assistance by governments, "for the more effective protection of the rights of owners of copyright," and to report at the next joint session of the Committee and the representatives of the Berne Union. ${ }^{80}$ This could prove to be the first step to protection less expensive and more effective than that required by the U.C.C.

\section{News Media, Double Taxation, and Works of Applied Art}

Other problems relating to the international protection of copyright or which may affect copyright are of considerable concern. They have related to the copyright protection of news and information media, ${ }^{81}$ to the problem of double taxation of copyright royalties, ${ }^{82}$ to the protection of works of applied art, designs and models, ${ }^{83}$ and to the field designated as neighboring on copyright, as well as numerous others.

${ }^{80}$ Resolution No. 28 (IV) Criminal proceedings in case of copyright infringement3, XII UNESCO COPYRIGHT BULLETIN 266 (No. 2, 1959).

${ }^{81}$ The Intergovernmental Copyright Committee considered that there was no reason to provide for a special protection of news and other press information through a new intellectual property right. Resolution No. 20 (III), XI UNESCO CoPYrighr BULLETIN $x 75$ (No. 2, 1958).

83 This was deemed to be a problem of international tax techniques within the province of the various governments to reduce by domestic legislation or by international tax agreements and lying within the province of the United Nations and not that of the Intergovernmental Copyright Committee. Resolution No. Ix (II) Double Taxation of Copyright Royalties, X UNESCO COPYRIGHT BULletin 228 (No. 2, 1957); Resolution No. 23 (III), XI UNESCO COPYRIGHT BuLLETIN 176 (No. 2, 1958).

${ }^{8 s}$ A Study Group on the International Protection of Works of Applied Art, Designs and Models met in Paris in April 1959. A Report of Dr. Arpad Bogsch, rapporteurgeneral, as adopted by the study group, appears in XII UNESCO COPYRIGHT BULIETIN 
Neighboring or Related Rights.

The great activity and productive effort which has occurred in regard to neighboring rights demands a rapid survey of recent occurrences.

Inevitable to the consideration of the rights of authors of intellectual materials in the form of story, play, song or motion picture, are the problems of the related rights in the artistic labors of those who interpret or perform the works, and whose renditions are captured in fixed tangible forms, such as audio or video recordings on phonograph records, discs, films, tapes or wire, capable of identical future reproduction, separate and apart from the performer, and having great value in the market place.

Except where recorded as integrated sound motion picture films, works of performers of artistic creation which are perceptible only audibly have not been protected under copyright in the United States, although they have achieved some protection under other fields of law. ${ }^{84}$

At the present time, there is considerable pressure in certain Western European countries for conventions to protect the rights of artistic performing artists, their record manufacturers, and radio and television broadcasters. In this respect, there have been two recent draft conventions: the Geneva draft of 1956 under the auspices of the International Labor Organization, ${ }^{85}$ and the 1957 Monaco draft ${ }^{86}$ under the joint auspices of UNESCO and the Berne Union. These drafts were

I (No. I, 1959). The study group was constituted pursuant to directions of the Intergovernmental Copyright Committee (U.C.C.), the Permanent Committee of the International Union for the Protection of Literary and Artistic Works (Berne Union) and the International Union for the Protection of Industrial Property (Paris Union) and has sent its report to those bodies and to the governments of member countries.

There was also a Diplomatic Conference on the International Deposit of Industrial Designs at The Hague, in November 1960, which resulted in an agreement signed by eleven states (Belgium, France, The Federal Republic of Germany, Holy See, Italy, Lichtenstein, Luxemburg, Monaco, The Netherlands, Switzerland and Yugoslavia). There was a United States delegation in attendance. See Bogsch, Diplomatic Conference on the International Deposit of Industrial Designs, 8 BULL. CR. Soc. 156 (196x).

${ }^{84}$ For a discussion of the theories employed by state courts, see Sargoy, supra note 47, at 822-25, 831-38; Note, Copyright "Neighboring Rights" or "Rights Neighboring on Copyright": Rights of Performing Artists, Recorders and Broadcasters, 43 CORNELI L.Q. 476, 477-78 (1958). See also note 54 supra.

${ }^{85}$ Prepared in Geneva, Switzerland in July 1956 as the "Proposed International Convention Concerning the Protection of Performers, Manufacturers of Phonographic Records and Broadcasting Organizations." See X UNESCO COPYRIGHT BuLlETIN 3237 (No. $x$, 1957).

${ }^{8}$ See X UNESCO COPYRight Bulletin 12-15 (No. 1, 1957). 
preceded by an initial effort in this area, the Rome draft of $1951,{ }^{87}$ and reflect different approaches to the problem. The ILO draft views the problem from a collective approach, in terms of the interests of the live labor displaced by recordings, and points towards a complete compulsory convention code to govern national as well as international situations in this area. On the other hand, the Monaco draft seeks to protect rights conceived of as purely individual in nature. Thus, it primarily seeks to protect remuneration for the performers involved, or their authorized assignees, the record manufacturers, and provides generally for local national treatment. ${ }^{88}$

In May 1960, there was a conference held at The Hague of experts nominated by various governments, on a non-diplomatic basis, with a view to reconciling, if possible, the conflicting ILO and Monaco drafts. A new joint draft resulted and will be submitted to the various governments for study and consideration, with a view to a future formal diplomatic conference at which the same can be fully considered ${ }^{80} \mathrm{~A}$ comparison of the ILO and Monaco drafts with The Hague draft would indicate the differences in approach, similarities and compromises. ${ }^{90}$

87 "The Preliminary Draft International Convention Regarding the Protection of Performers, Manufacturers of Phonographic Records and Broadcasting Organizations" adopted in Rome on November 17, 1951 under the combined auspices of representatives of the International Labor Organization and the Berne Union.

${ }^{8}$ Art. 2, para. 1 ; art. 3, para. 1; art. 5, para. 1.

${ }^{80}$ The Draft International Convention concerning the Protection of Performers, Makers of Phonograms, and Broadcasters, was the product of a committee of experts meeting at The Hague in May 1960. Intergovernmental Copyright Committee Resolution No. $3_{8}^{8}(\mathrm{~V})$ indicates that the Directors General of the International Labor Organization and UNESCO, and the Director of the Berne Bureau, in agreement with the Government of Italy, should convene the Diplomatic Conference for the Adoption of an International Convention, in Rome, not earlier than October of 1961.

${ }^{\circ}$ A. Performing Artists.

The ILO and Monaco drafts protect artistic renditions and interpretive fixations and broadcasts by preventing sub rosa recordings and fixations of "live" performances without the performer's consent, express or tacit. Article five of The Hague draft provides the same protection. When a performance has authorizedly been captured on a recording, the performing artist is given the right to authorize or prohibit the duplication of his recording in all three drafts. A difference in approach is seen in the handling of receipts from recorded performances. The Monaco draft secks license fecs as additional compensation for the performing artist, or his contracting record manufacturer, while the ILO draft would place the receipts in collective funds, such as labor union treasuries, for unemployed performers. The Hague draft (article $5(3)$ ) is a compromise allowing individual contract terms or collective agreements, where national legislation so permits. The protection afforded by these drafts is at least equal to the present legal protection available in the United States under principles of law other than copyright. 
In the meantime, the United States is observing carefully, although taking no leading part, possibly because of misgivings of various financially interested groups who see the possibility of new and unknown individual relationships, as well as potential new organizations or societies with which to deal or compete.

\section{IV}

\section{Conclusion}

International cooperation, with the active participation of the United States, toward securing a wide recognition throughout the world of the fundamental rights of authorship has been all too long in coming. With the recent taking effect of the Universal Copyright Convention, with the United States a participant, and the recent increase in interest and activity, both in copyright and related fields, of divers countries, there is a clear indication of a profound concern and willingness to come to grips with the need for greater international protection of copyright and related areas. The joint meetings and discussions of representatives of the U.C.C., the Berne Union, and other more particularized groups, on the ever-arising problems ancillary to the exchanges of intellectual and cultural creations, signal the first phase of a more meaningful in-

\section{B. Recorders}

Under the ILO draft the recorder is any manufacturer of the first finished copy of the record, whereas article three of the Monaco draft refers to that person who first fixes a performance, or its sounds, in material form. The Hague draft employs the phrase "Maker of Phonograms" to mean the person or corporate body who first fixes a performance or other sounds in material form (article 10). The ILO draft, article six, and The Hague draft, article eleven, recognize the recorder's right to receive an equitable remuneration for the public communication and broadcast of his record. The Hague draft, article eight, also embodies the Monaco provision granting the recorder the right to authorize or prohibit the copying of his record. The protection to be extended is as complete as that offered in the United States.

\section{Broadcasters}

This term usually refers to the person controlling the aural or visual, or combined, transmission of radio or television communications intended to be received by the public. All drafts recognize the broadcaster's right to authorize or prohibit: (1) relaying or rebroadcasting; (2) off-the-air fixation of a broadcast for profit; and (3) the receipt and projection on a screen, in public, of a television broadcast. The drafts would provide as complete protection as is available under state law in this country.

The Monaco draft would allow individual countries to make reservations in adhering, as to any of the basic elements of protection, while the ILO draft would make its provision generally mandatory. All of the above provisions of the Hague draft are optional. 
ternational protection of copyright: Recent cultural exchanges between Western nations and "Iron Curtain" countries, especially the United States and the Soviet Union; may be the harbinger of greater inclusion of the "Iron Curtain" nations. in international copyright discussions and agreeinents.

Although there is a great chasm to cross, perhaps we may expect, in the not too distant future, agreement among all the nations of the world, regardless of political ideology, as to the protection to be afforded works produced by the intellectual genius of man. 